\title{
A Review on Fault Current Limiting Devices to Enhance the Fault Ride-Through Capability of the Doubly-Fed Induction Generator Based Wind Turbine
}

\author{
Seyed Behzad Naderi ${ }^{1}{ }^{(}$, Pooya Davari $^{2}$, Dao Zhou ${ }^{2}$, Michael Negnevitsky ${ }^{1, *}$ (D) and \\ Frede Blaabjerg ${ }^{2}$ (D) \\ 1 School of Engineering, University of Tasmania, Hobart, TAS 7005, Australia; \\ Seyedbehzad.Naderi@utas.edu.au \\ 2 The Department of Energy Technology, Aalborg University, 9220 Aalborg, Denmark; pda@et.aau.dk (P.D.); \\ zda@et.aau.dk (D.Z.); fbl@et.aau.dk (F.B.) \\ * Correspondence: michael.negnevitsky@utas.edu.au; Tel.: +61-362-267-613
}

Received: 27 September 2018; Accepted: 23 October 2018; Published: 25 October 2018

\begin{abstract}
The doubly-fed induction generator has significant features compared to the fixed speed wind turbine, which has popularised its application in power systems. Due to partial rated back-to-back converters in the doubly-fed induction generator, fault ride-through capability improvement is one of the important subjects in relation to new grid code requirements. To enhance the fault ride-through capability of the doubly-fed induction generator, many studies have been carried out. Fault current limiting devices are one of the techniques utilised to limit the current level and protect the switches, of the back-to-back converter, from over-current damage. In this paper, a review is carried out based on the fault current limiting characteristic of fault current limiting devices, utilised in the doubly-fed induction generator. Accordingly, fault current limiters and series dynamic braking resistors are mainly considered. Operation of all configurations, including their advantages and disadvantages, is explained. Impedance type and the location of the fault current limiting devices are two important factors, which significantly affect the behaviour of the doubly-fed induction generator in the fault condition. These two factors are studied by way of simulation, basically, and their effects on the key parameters of the doubly-fed induction generator are investigated. Finally, future works, in respect to the application of the fault current limiter for the improvement of the fault ride-through of the doubly-fed induction generator, have also been discussed in the conclusion section.
\end{abstract}

Keywords: fault current limiters; doubly-fed induction generator; fault ride-through; superconductor; series dynamic braking resistor

\section{Introduction}

With the high penetration level of wind energy conversion systems in the grid, power system operators encounter new challenging issues, which could affect the stability of the power system. Therefore, keeping the wind turbines connected to the grid during faults with high wind power penetration is important, which is known as fault ride-through (FRT) capability [1].

Due to many significant characteristics of doubly-fed induction generator (DFIG) based wind turbines, they are widely employed in the power system, especially for the multi-megawatt applications [2]. In the configuration of the DFIG, the stator of the DFIG is directly connected to the grid, and the rotor circuit is linked to the network by partial-scale back-to-back voltage source converters. During the fault condition, a transient over-current goes through the rotor circuit towards 
the rotor side converter (RSC). The rotor over-current can either trip out the DFIG or damage the power electronic devices [3]. Therefore, keeping the DFIG based wind turbine connected to the utility and preventing the equipment from damage are important during the fault. For secure power system operation, the wind turbines should meet the grid requirements. The FRT requirement varies from country to country, following characteristics of the power system as shown in Figure 1 [4]. Among the different grid codes, which are regulated by the various operators, the E.ON grid code has the most severe FRT requirements [1,5]. With regard to E.ON grid code, even if the point of the common coupling (PCC) voltage drops to zero for $150 \mathrm{~ms}$ after the fault occurrence, the wind turbine must not be disconnected from the grid.

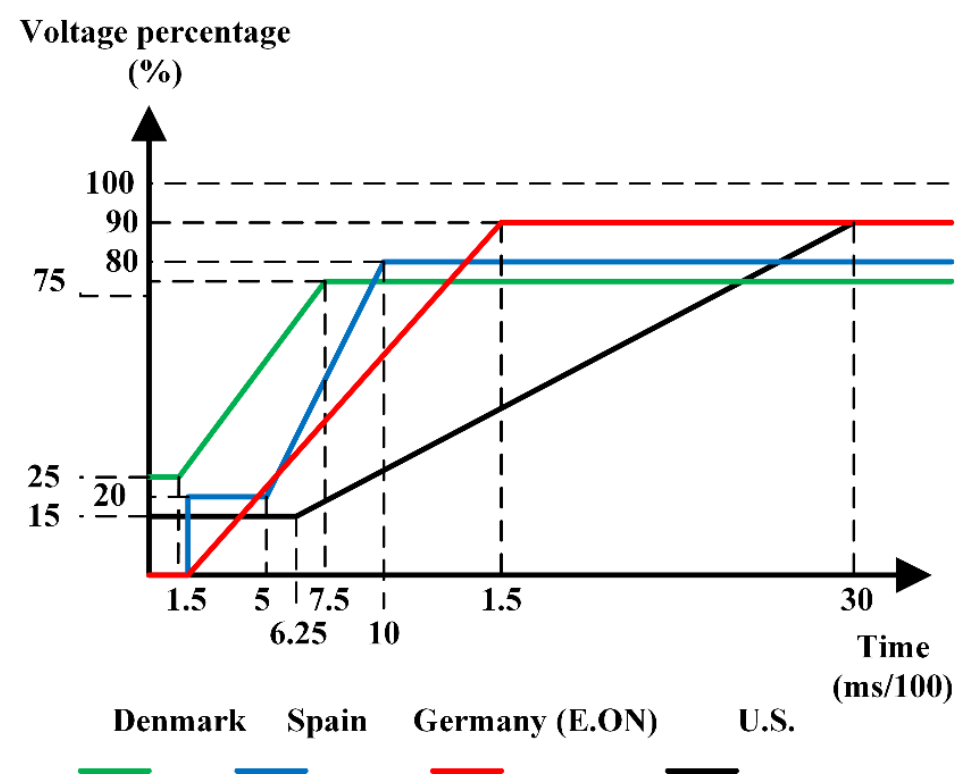

Figure 1. The grid code requirement for the fault ride-through of the wind turbine in the different countries [4]. Adapted with permission from [4], Copyright Publisher, 2015.

In the literature, different methods have been studied to enhance the FRT capability of the DFIG [6]. The previous introduced approaches can be classified as crowbar (active and passive) [7,8], DC braking chopper [9], new configurations for the DFIG [10,11], the advanced control techniques in back-to-back voltage source converters [12], and adding new hardware into the DFIG.

When adding new hardware into the DFIG, one of the common techniques is to employ fault current limiting devices to improve the FRT capability of the DFIG. Fault current limiters (FCLs) and series dynamic braking resistors (SDBRs) are placed in series connection, in different locations, in the DFIG (the stator side, the terminal, the DC link between the RSC and the DC-link capacitor, and the rotor side). In this paper, a review of most of the existing literature, which investigates the fault current limitation in the DFIG, is carried out. To improve the FRT capability of the DFIG, different configurations of the FCLs have been employed. Figure 2 shows the diagram of all employed FCLs to enhance the FRT capability of the DFIG. The operational behaviour of each configuration is briefly discussed in normal and fault conditions. The FCL structures can be categorized with respect to their impedance type during the fault condition. In the simulation section, the impedance type and the FCL's location will be discussed, which have various impacts on the key parameters of the DFIG. In this review, the detailed operation of the configurations is not considered, only the functionality is considered. Moreover, the steady state of the fault condition is discussed, which essentially depends on the type and size of the impedance in the fault current limiting devices. 


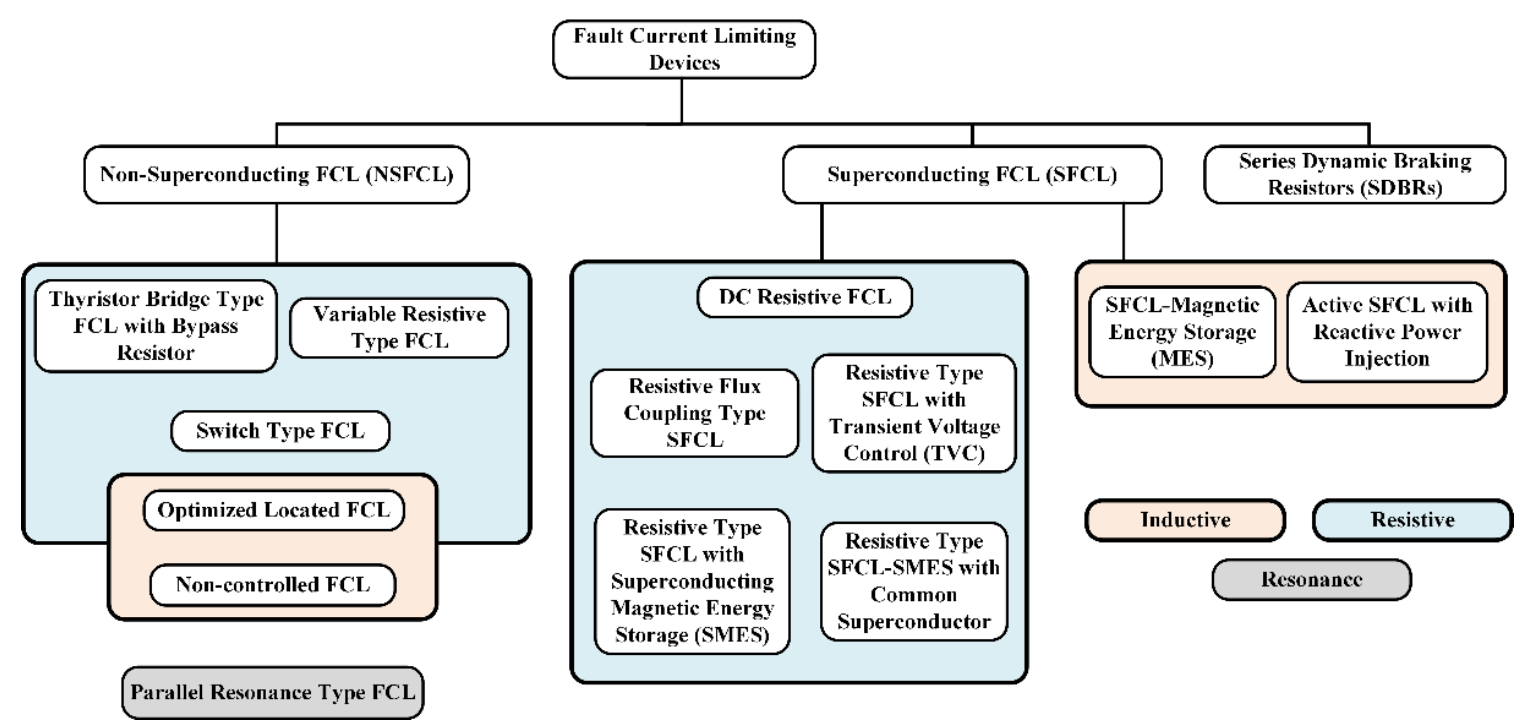

Figure 2. Diagram of the fault ride-through (FRT) capability enhancement by fault current limiting devices in the doubly-fed induction generator. FCL: Fault current limiter.

In the following, the operation of the DFIG is briefly expressed with the RSC's and grid side converter (GSC)'s control circuits. In Section 3, other approaches are mentioned with their pros and cons. In Section 4, an overview of almost all fault current limiting devices is studied, with their configuration and behaviour in normal condition and in the fault condition. Section 5 shows how the impedance and the location of the fault current limiting devices affect the operation of the DFIG in the steady state of the fault condition. Furthermore, a discussion is raised on the simulation results. Finally, a conclusion is given.

\section{Doubly-Fed Induction Generator}

The configuration of the DFIG is shown in Figure 3A. During the fault condition, a very high electromotive force (EMF) is induced in the rotor due to the electromagnetic interaction with the stator and the rotor of the DFIG, which leads to over-voltage and over-current in the rotor side. The over-voltage and the over-current could damage the RSC components if the semiconductor switches are continuously trigged in the fault condition. In this situation, the rotor high-transient over-current passes through the switches.

Meanwhile, the excess active power, which is not able to be delivered to the power system in the fault condition, charges the DC-link capacitor and rapidly increases the DC-link voltage. So, with regard to Figure $3 \mathrm{~A}$, the DC braking chopper typically operates to dissipate the excess energy and keep the DC-link voltage $\left(V_{D C}\right)$ in a constant value. It should be noted that, because of the operation of the DC braking chopper and the time-varying characteristics of the electromagnetic interaction with the stator and the rotor, the response of the DFIG is very non-linear. However, during the fault, the DC-link voltage is almost kept constant when the DC braking chopper operates. In a static stator-oriented reference frame, the rotor and the stator fluxes, $\vec{\psi}_{r}, \vec{\psi}_{s}$, and the rotor and the stator voltages, $\vec{v}_{r}, \vec{v}_{s}$, are expressed as follows with respect to the Park model of the DFIG [13]:

$$
\begin{gathered}
\vec{v}_{s}=R_{s} \vec{i}_{s}+\frac{d \vec{\psi}_{s}}{d t} \\
\vec{v}_{r}=R_{r} \vec{i}_{r}+\frac{d \vec{\psi}_{r}}{d t}-j \omega_{r} \vec{\psi}_{r} \\
\vec{\psi}_{s}=L_{s} \vec{i}_{s}+L_{m} \vec{i}_{r}
\end{gathered}
$$




$$
\vec{\psi}_{r}=L_{m} \vec{i}_{s}+L_{r} \vec{i}_{r}
$$

whereby $\vec{i}, \omega, R$, and $L$ represent current, angular frequency, resistance, and inductance, respectively. Additionally, stator, mutual, and rotor parameters are mentioned by subscripts of $s, m$, and $r$, respectively. By means of (3) and (4), $\vec{\psi}_{r}$ is computed with respect to $\vec{i}_{r}$ and $\vec{\psi}_{s}$. (5) expresses $\vec{\psi}_{r}$ as follows:

$$
\left\{\begin{array}{c}
\vec{\psi}_{r}=\frac{L_{m} \vec{\psi}_{s}}{L_{s}}+\sigma L_{r} \vec{i}_{r} \\
\sigma=1-\frac{L_{m}^{2}}{L_{s} L_{r}}
\end{array}\right.
$$

whereby the leakage coefficient is represented by $\sigma$. To calculate the rotor voltage with respect to (2) and (5), the following expression is deduced:

$$
\vec{v}_{r}=\overbrace{\frac{L_{m}}{L_{s}}\left(\frac{d}{d t}-j \omega_{r}\right) \vec{\psi}_{s}}^{\vec{v}_{r o}}+\left(R_{r}+\sigma L_{r}\left(\frac{d}{d t}-j \omega_{r}\right)\right) \vec{i}_{r}
$$

whereby $\vec{v}_{r o}$ denotes the rotor voltage when the rotor is in an open circuit condition and the rotor current is zero. If the reference frame is changed from a static stator-oriented reference frame to a rotor-oriented reference frame, the rotor voltage is expressed in (7):

$$
\vec{v}_{r}^{r}=\vec{v}_{r o}^{r}+\left(R_{r}+\sigma L_{r} \frac{d}{d t}\right) \vec{i}_{r}^{r}
$$

whereby $\vec{v}_{r}^{r}, \vec{v}_{r o}^{r}$, and $\vec{i}_{r}^{r}$ are the rotor voltage, the open circuit rotor voltage, and the rotor current in the rotor-oriented reference frame, respectively. With regard to (7), the rotor side electrical circuit is modelled by a three-phase voltage source of $\vec{v}_{r o}^{r}$, the rotor resistance $\left(R_{r}\right)$, and the transient inductance $\left(\sigma L_{r}\right)$ during the fault condition. The level of rotor transient over-current will be changed with regard to the fault instant, the type of fault, and the voltage sag depth [14]. For instance, during a symmetrical grid fault, the open circuit rotor voltage $\left(\vec{v}_{r o}^{r}\right)$ includes two expressions as follows:

$$
\vec{v}_{r o}^{r}=(1-p) V_{s} \frac{L_{m}}{L_{s}} s e^{j s \omega_{s} t}-\frac{L_{m}}{L_{s}}\left(\frac{1}{\tau_{s}}+j \omega_{r}\right) \frac{p V_{s}}{j \omega_{s}} e^{-j \omega_{r} t} e^{\frac{-t}{\tau_{s}}}
$$

whereby the pre-fault stator voltage magnitude, the voltage sag depth, and the slip are represented by $V_{s}, p$, and $s$ during the symmetrical grid fault, respectively. Also, $\tau_{s}$ decaying time constant is equal to $L_{S} / R_{S}$.

The schematic of control circuits for the rotor side converter and the grid side converter are presented in Figure 3B [15]. In both control systems, proportional-integral (PI) controllers are employed for regulation. In the rotor side converter, the reference active power $\left(P_{r e f}\right)$ is computed in respect to maximum power point tracking and then the extracted active power $\left(P_{\text {extract }}\right)$, which depends on the wind speed, is compared to $P_{\text {ref. }}$. Consequently, the $d$-axis reference current of the rotor is achieved. Meanwhile, the reference value for the reactive power of the stator $\left(Q_{s-r e f}\right)$ is considered zero. Therefore, during the normal operation, the absorbed reactive power $\left(Q_{s}\right)$ from the stator side of the DFIG will be equal to the reference value, and the required reactive power for the DFIG will be covered by the back-to-back converters. To maintain the DC-link voltage in constant value, the grid side converter provides the active power to the rotor side. Therefore, the $d$-axis reference current is obtained by comparing the DC-link voltage with the reference value $\left(V_{D C-r e f}\right)$. Meanwhile, the reactive power $(Q)$ in the GSC and the RSC is adjusted by the reference value of $Q_{\text {ref }}$. 


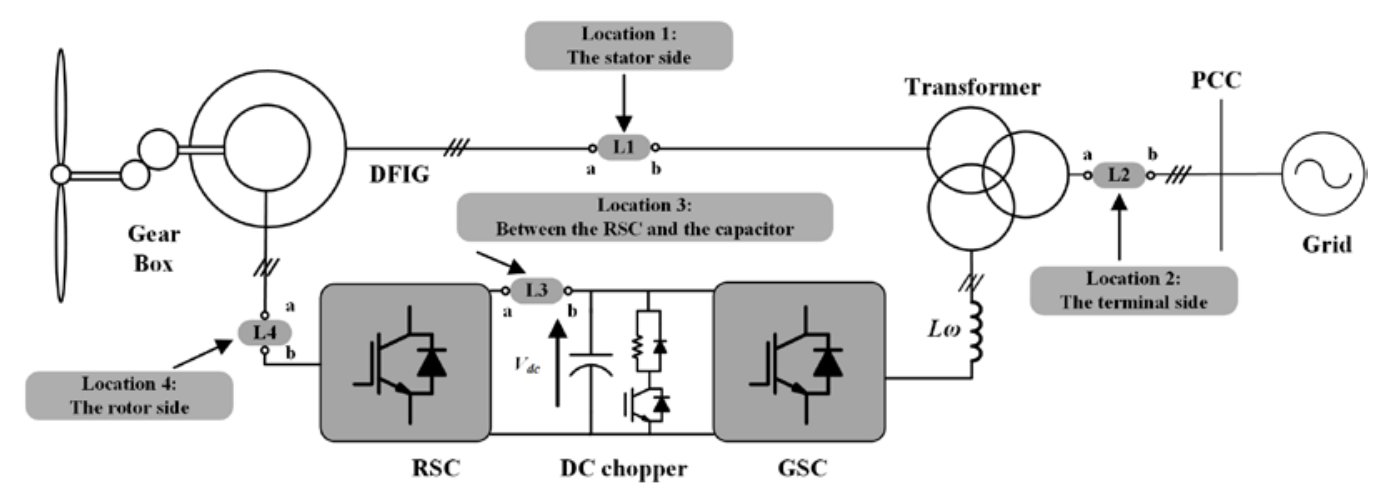

(A)
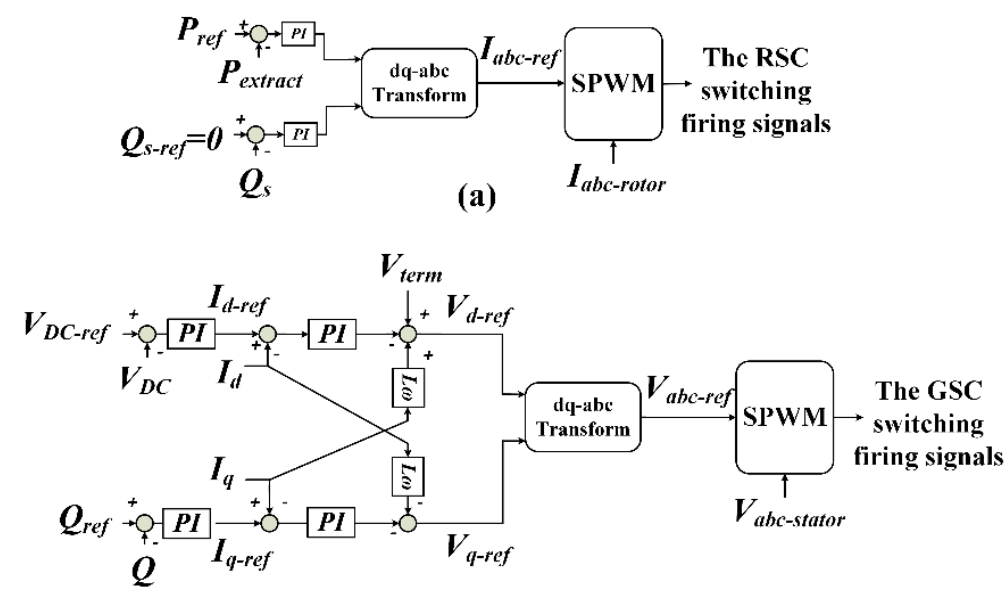

(b)

(B)

Figure 3. (A) The doubly-fed induction generator (DFIG) configuration, with all possible highlighted locations for the fault current limiters and series dynamic braking resistors, in the fault ride-through capability improvement. RSC: Rotor side converter; GSC: Grid side converter; PCC: Point of the common coupling. (B) The schematic of control circuits for: (a) The rotor side converter; and (b) the grid side converter [15]. Adapted with permission from [15], Copyright Publisher, 2017.

\section{Fault Ride-Through}

As mentioned in the introduction, there are different methods to improve the FRT capability of the DFIG. Advanced control methods are discussed mostly in the research papers. These methods control active and reactive power injections, of the DFIG, to restore the PCC voltage during the fault. Most of these methods are complicated and thus they are not so interesting for the industry [16]. Furthermore, during the zero-voltage sag in the PCC, the terminal voltage, as a reference, will be lost and the control method might be inapplicable [17].

Another method is to change the configuration of the DFIG. In this situation, the changes happen in the back-to-back converters. A fault-tolerant DFIG-based wind turbine has been proposed to enhance the FRT capability [10,18]. The configuration of the proposed DFIG is shown in Figure 4. Instead of utilising a general, six-semiconductor-switch converter, a nine-switch GSC has been used. In normal operation, three lower switches are in the on state. When a fault occurs, three lower switches operate to compensate the voltage on the neutral side of the winding in the stator. Another change in the configuration of the conventional DFIG has been studied in [11,19]. The proposed scheme is shown in Figure 4, in grey. Similar to the conventional DFIG, the stator is directly linked to the grid through the terminal. However, an extra converter, which is connected to the star point of the stator winding, is employed to provide an effective active power transfer to the grid, and a better power 
system disturbance ride-through during the low voltage. As it is clear from Figure 4, these changes in the configuration of the conventional DFIG are probably not of interest to industry. However, to be practically implemented, they should have economical justification.

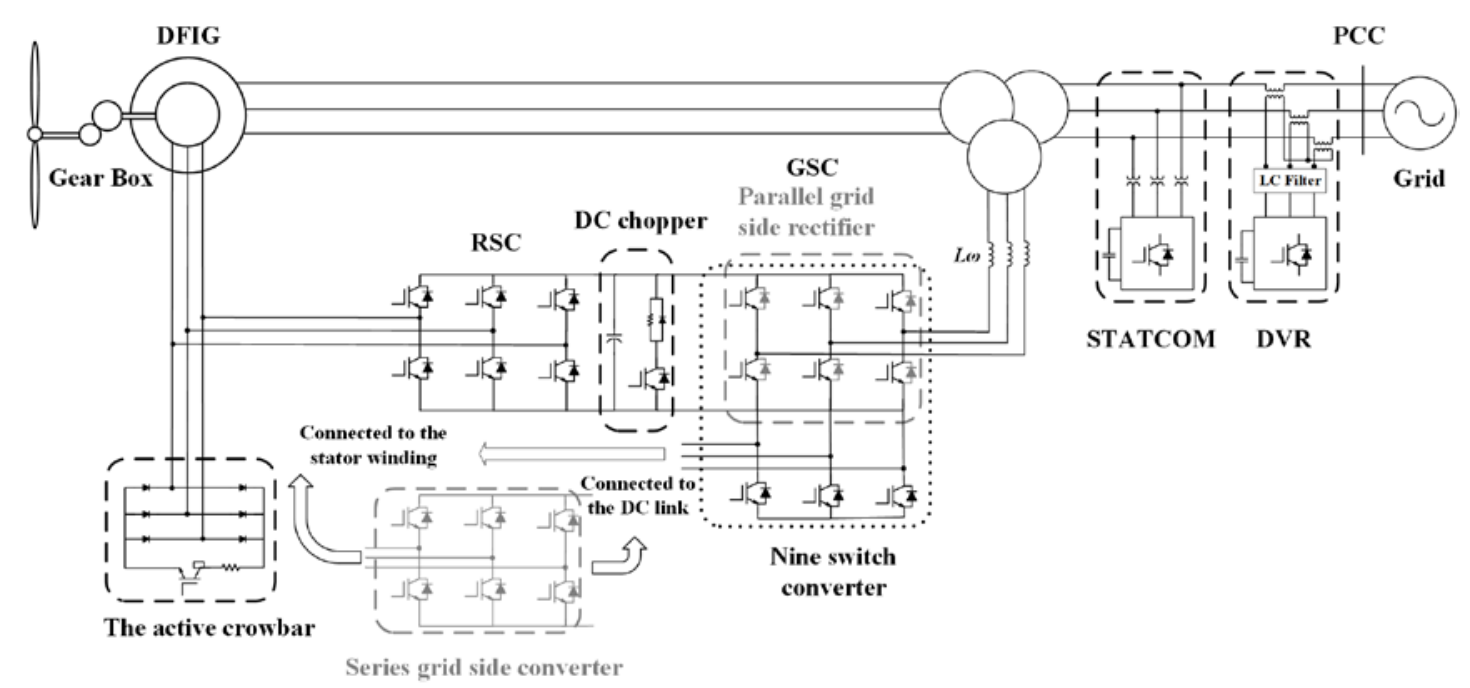

Figure 4. The doubly-fed induction generator (DFIG) configuration with the most well-known fault ride-through (FRT) enhancement approaches. DVR: Dynamic voltage restorers; STATCOM: Static synchronous compensator.

Adding extra hardware is another scheme to improve the FRT capability of the DFIG. Crowbar protection, DC braking chopper, voltage sag compensation devices, and fault current limiting devices are employed as extra hardware in the DFIG to enhance the ride-through capability during the fault condition. The crowbar protection is the most well-known scheme, which is practically employed and utilised in the FRT improvement of the DFIG. The configuration of the crowbar is shown in Figure 4. The crowbar includes a three-phase diode bridge rectifier, a bypass resistance, and a switch (either a semiconductor switch, such as an isolated gate bipolar transistor in the active crowbar, or a switch such as a thyristor in the conventional crowbar). The active crowbar has been introduced to overcome the continuous absorption of the reactive power by the squirrel-cage induction generator in the conventional crowbar [7]. To operate the active crowbar by a semiconductor switch and cease the RSC switching, a threshold current or a threshold voltage is defined regarding the transient over-current in the rotor side or the over-voltage in the DC link, respectively. Whenever the measured current voltage is less than the threshold current voltage, the DFIG converters resume to normal operation [8]. The RSC stop and the reactive power absorption by the active crowbar are the main disadvantages of this method.

DC braking chopper is another scheme to keep the DC-link voltage value in the safe area of operation during the fault condition. The schematic of the DC chopper is depicted in Figure 4. The parallel connected configuration of the DC chopper consists of a resistor in series with a semiconductor switch. An anti-parallel diode is also utilised to protect the chopper switch from voltage spike when the semiconductor switch goes to the off state. However, the DC braking chopper does not effectively restrict the rotor transient over-current. Therefore, high-rated anti-parallel diodes should be employed in the RSC [9]. Similar to the crowbar scheme, when the DC chopper is activated, the RSC switching is ceased.

A static synchronous compensator (STATCOM), as the voltage sag compensation device, has been discussed in [20]. Figure 4 shows the location and simple configuration of the STATCOM. Due to the low capacity of back-to-back converters, in case of the fault in the weak utility, there is a possibility of a voltage instability. Accordingly, voltage sag compensation devices, such as the STATCOM, have been proposed to support the voltage profile during the fault condition. There are 
coordinated and independent reactive power controls between the STATCOM and the DFIG [20,21]. In the independent control method, the voltage control is only done by the STATCOM. The STATCOM should be incorporated with a fault current limiting method because it is not solely able to restrict the fault current level in the RSC. Also, the dynamic voltage restorer (DVR) is another voltage sag compensation device, which have been utilised to overcome voltage sag during the fault. In Figure 4, the simple configuration of the DVR is presented. Similar to the STATCOM, auxiliary methods should be incorporated with the DVR, such as changing the control method of the back-to-back converters or the pitch angle control [22]. It should be noted that these mentioned devices require large storage capacity and a high number of semiconductor switches.

From a fault current limiting point of view, the FCLs and the SDBRs are employed to restrict the fault current level in the DFIG. Up until now, many configurations of FCLs have been proposed and studied. The FCL structures can be divided into two categories, with regard to impedance type and components. Considering the impedance type, they are resistive, inductive, resistive-inductive, and resonance type FCLs. Meanwhile, whether a superconductor is utilised or not, there is another category [23]. Recently, a new approach of applying the FCLs has been proposed that has the capability of producing variable resistance [24]. Considering the component type, the FCLs are either a solid state or saturated core transformer [14]. Despite the current limiting characteristics of the FCLs, they have been employed for different applications. From a transient stability point of view, the application of variable and controllable resistance FCLs has been proved [24]. Regarding the location of the FCLs, they are also employed to compensate the voltage sag in the PCC [25].

In order to improve the FRT capability of the DFIG, the FCLs are placed in different locations of the DFIG. Figure 3A shows the studied locations in the literature. In each location, with respect to the FCL impedance type, the impacts on the key parameters of the DFIG are different during the fault condition. From the FCL's location point of view, the FCLs are mostly located at the terminal side and the stator side of the DFIG. Some of the FCLs are placed in the rotor side and a few of the configurations are in the DC link. Meanwhile, from an impedance point of view, the FCLs are mostly the resistive type, as it is clear from Figure 2. In the following section, it will be discussed how the impedance type and the FCL's location could affect the FRT capability of the DFIG based wind turbine. The potential best choice of location and impedance type, in order to obtain the most favourable FRT capability of the DFIG, will be mentioned. In the following section, the FCLs' structures are categorized based on the impedance type.

\section{Fault Current Limiting Devices}

As mentioned, the FCLs and the SDBRs are employed as the fault current limiting devices to enhance the FRT capability of the DFIGs. At first, different structures of the FCLs and SDBRs are studied regarding the impedance type of each configuration, and then a comparison will be finally done.

\subsection{Non-Superconducting FCL}

\subsubsection{Inductive Type FCL: Non-Controlled FCL}

In [26], a cost-effective topology of a non-controlled FCL, to improve the FRT capability of the DFIG, has been studied. The non-controlled FCL is placed in the rotor side, which is shown in Figure 5a. Its configuration is similar to a three-phase bridge type FCL. The limiting inductance is a non-superconductor (NSC), which is cost-effective from an industrial point of view. Regarding the location of the FCL, inserting the NSC either in the stator side or in the rotor side has different impacts. When the non-controlled FCL is located in the stator side, regarding (9) and (10), the value of back-EMF voltage and the transient inductance of the rotor are changed as follows:

$$
\vec{V}_{0 r}=\frac{L_{m}}{L_{S}+a^{2} L_{F C L}} \frac{d \vec{\psi}_{s}}{d t}
$$




$$
\sigma_{L 1-F C L}=1-\frac{L_{m}^{2}}{\left(L_{s}+a^{2} L_{F C L}\right) L_{r}}
$$

Figure $5 b$ shows the variation of the leakage coefficient by changing the FCL's impedance. As it is clear by (9), by increasing the inductance of the FCL in the stator side, the value of rotor back-EMF voltage decreases. Therefore, the RSC has a good controllability in order to counteract the stator flux oscillations. However, the absolute value of the leakage coefficient significantly decreases and damps by increasing the FCL's inductive impedance. In fact, there is the possibility that the rotor transient over-current is not restricted to an acceptable range. It should be mentioned that, by locating the FCL in the stator side, the stator voltage is resumed to some extent. By placing the FCL in the rotor side, the leakage coefficient is expressed as follows:

$$
\sigma_{L 4-F C L}=1-\frac{L_{m}^{2}-a^{2} L_{F C L} L_{s}}{L_{s} L_{r}}
$$

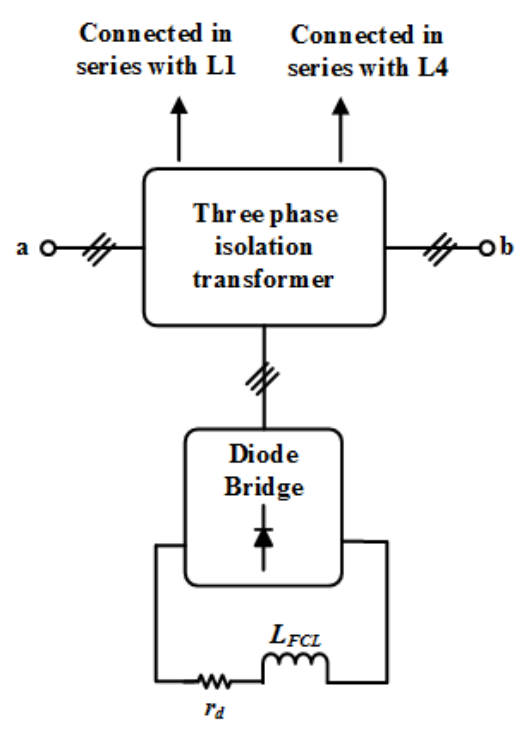

(a)

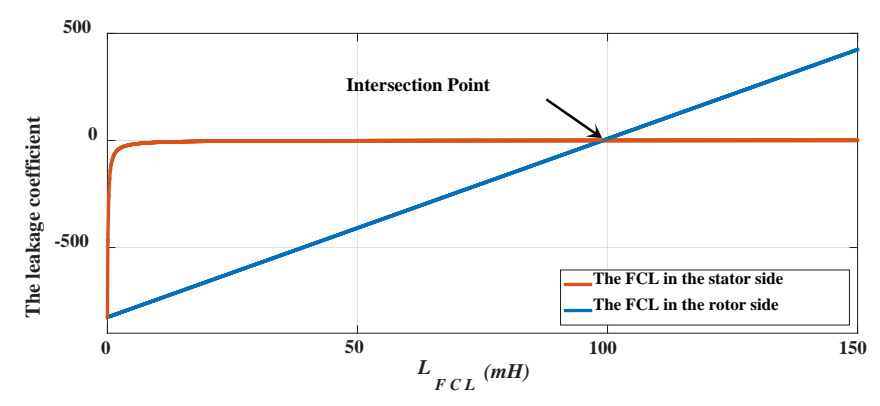

(b)

Figure 5. (a) The non-controlled inductive fault current limiter [26]; and (b) the leakage coefficient variation, with the FCL inductance variation in the stator and the rotor sides.

When the inductive FCL is located in the rotor side, the variation of the leakage coefficient is also shown in Figure $5 b$. In order to find out the variation of the leakage coefficient, some points should be considered. For the inductive FCL located in the rotor side, any impedance value lower or higher than the intersection point of curves could result in good rotor transient over-current limitation. Otherwise, the FCL could have an inverse impact on limiting the rotor transient over-current. As a result, if the inductive FCL is going to be in the rotor side, its impedance should be lower or higher and far away 
than from the intersection point of the curves in order to achieve a good current limitation capability. However, it should be noted that, from limiting the rotor transient over-current perspective, the inductive FCL in the rotor side is more effective than placing the FCL in the stator side. Furthermore, it should be noted that the rotor back-EMF voltage remains unchanged and, consequently, a rather high electromagnetic torque oscillation might occur due to the weak controllability of the RSC on the stator flux linkage. In addition, there is no possibility to restore the stator voltage.

\subsubsection{Inductive-Resistive Type FCL: Optimized Located FCL}

An optimized located FCL has been proposed in [27], and it is shown in Figure 6. The proposed FCL has been placed in the DC link of the DFIG. However, the RSC switches are turned off during the fault condition, and high-level fault currents pass through the high-rated anti-parallel diodes. The FCL is resistive and is capable of limiting the fault current only in one direction. The FCLs' resistance is bypassed by a semiconductor switch during normal condition. To protect the semiconductor switches in the FCL from over-voltage, a surge arrestor is connected in parallel with each switch of the FCL. It should be noted that the optimized located FCLs can cause over-voltage on the RSC switches during the switching in normal operation. To avoid this destructive voltage, auxiliary circuits should be applied, which result in a high cost and large size.

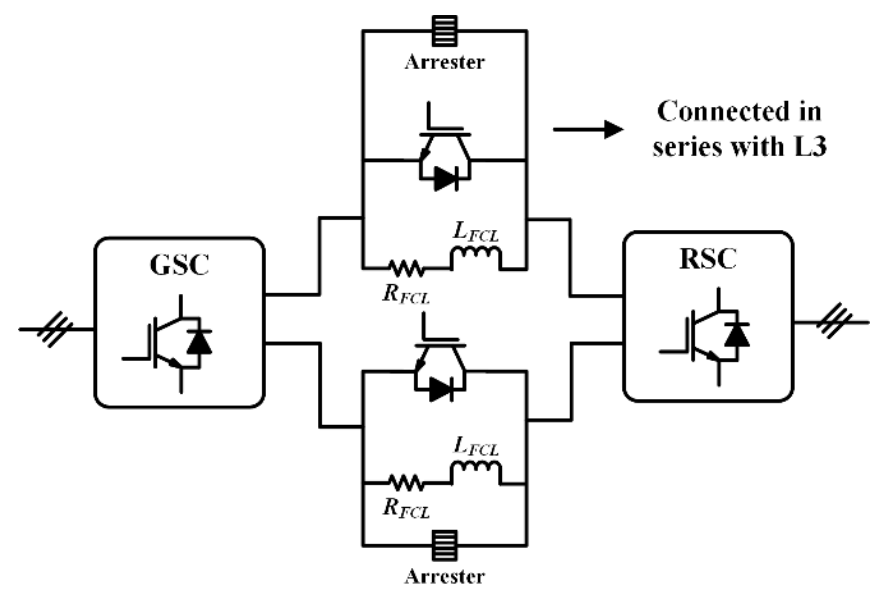

Figure 6. The optimized located FCL [27].

\subsubsection{Resistive Type FCL: Thyristor Bridge Type FCL}

A thyristor bridge type FCL with bypass resistor (BTFCL-BR) has been presented in [28]. Figure 7a shows the BTFCL-BR. In [28], the stator side location has only been studied. The main advantage of the BFCL-BR is the use of the NSC. Because of employing the NSC, there are high voltage spikes on it, which affect the stator voltage and, consequently, generate severe stator flux and electromagnetic torque oscillations during normal operation. Therefore, the bypass resistor (BR) has been proposed, not only to restrict the high voltage spikes but also to eliminate the current harmonics in normal operation of the power system. During the fault condition, after fault detection, the signal triggering of the thyristors will go to the off state. So, before turning off the thyristors in the zero-current crossing, the bypass resistor and the NSC restrict the stator fault current in the first instances of the fault. After turning off all thyristors, the bypass resistance solely limits the stator fault current. Increasing the resistance in the stator side decreases the time constant of the stator current and, in the meantime, restricts the stator fault current in a good manner. The number of thyristor switches employed can be a disadvantage for this configuration. 


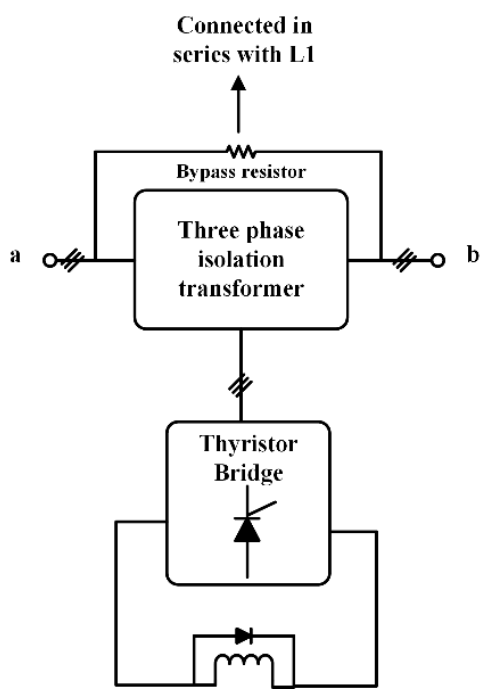

(a)

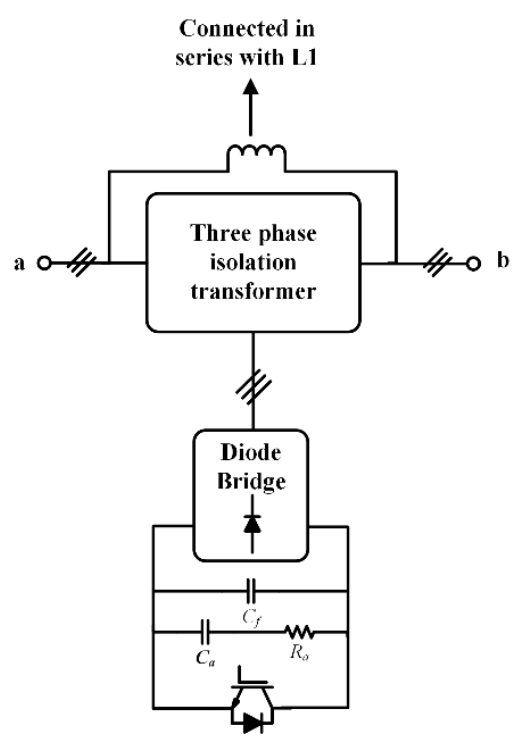

(b)

Figure 7. (a) The thyristor bridge type fault current limiter with bypass resistor (BTFCL-BR) [28]; and (b) the switch type fault current limiter (STFCL) with a snubber circuit [14].

\subsubsection{Resistive Type FCL: Switch Type FCL (STFCL)}

An STFCL has been proposed in [14], and it is shown in Figure 7b. The STFCL, compared to the BTFCL, uses an inductor as a fault-current-limiting impedance instead of the BR. Furthermore, instead of using a thyristor bridge, a diode bridge has been employed in the STFCL, which decreases the installation cost. A snubber circuit has been used in order to utilize the inductor to suppress the transient over-voltage on the semiconductor switch, when it goes to the off state after the fault detection. After suppressing the first spikes by $C_{f}$, which is smaller than $C_{a}, C_{a}$ absorbs the excess energy in the stator until its voltage reaches a steady state. Afterwards, the current pass, in the DC side of the diode bridge, is blocked and the inductor does its limiting operation. The STFCL's impact on the DFIG is the same as has been discussed for the non-controlled FCL located in the stator side. 


\subsubsection{Resistive Type FCL: Variable Resistive Type FCL}

In [29], a variable resistive type FCL (VR-FCL) has been placed in the PCC to improve the transient stability of a hybrid power system, including the DFIG, a Photovoltaic (PV) plant, and a synchronous generator. The configuration of the VR-FCL is similar to [30] and is shown in Figure 8a. However, to make better transient stability improvement, the pre-fault conditions, including the pre-fault active power of the hybrid generation units and fault location, have been taken into account. Regarding the pre-fault conditions, to control the VR, three nonlinear controller schemes, including fuzzy logic controller (FLC), static nonlinear controller (SNC), and an adaptive-network-based fuzzy inference system (ANFIS) have been discussed. The operation of the ANFIS-based VR-FCL is better than the FLC, and the FLC is better than the SNC. The factors to evaluate the operation of each controller are the rotor speed deviation of the DFIG, the DC-link voltage deviation of the PV generator, and the load angle deviation of the synchronous generator. The concept of the pre-fault conditions to achieve the maximum transient stability has been previously proposed in [30]. However, it should be noted that the dynamic behaviour of the DFIG is completely different than that of the other generation units [13]. As soon as the fault happens, especially the three-phase fault, the voltage drop on the FCL cannot be enough due to the exponential current variation in the stator of the DFIG, particularly after damping the stator current in the first cycles of the power system frequency.

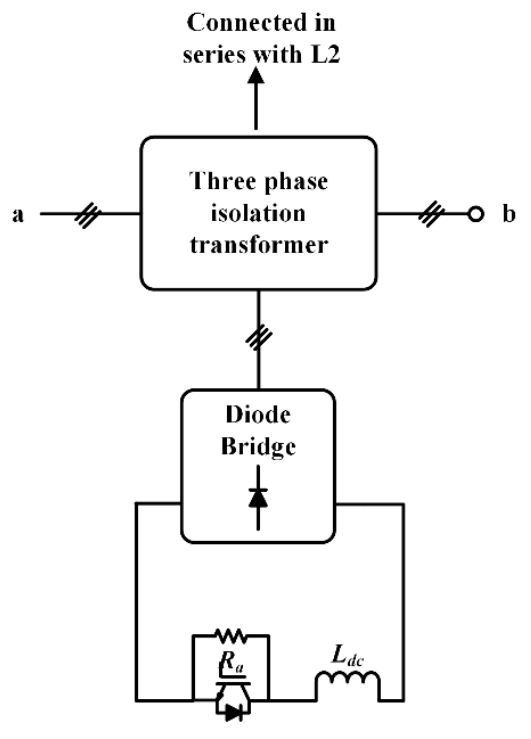

(a)

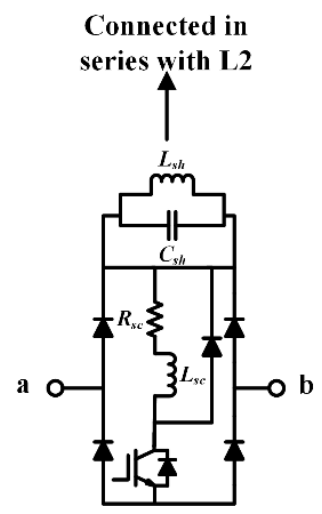

(b)

Figure 8. (a) The variable resistive type fault current limiter (VR-FCL) [29]; and (b) the parallel resonance type fault current limiter [31]. 


\subsubsection{Resonance Type FCL: Parallel Resonance Type FCL}

In [31], as shown in Figure 8b, a parallel resonance type FCL has been investigated and compared to the bridge type FCL with parallel resistive-inductive shunt impedance. The idea of parallel resonance type FCL has been proposed in [32]. In normal operation, the semiconductor switch is in the on state and the parallel resonance is bypassed. After a fault occurrence, the semiconductor switch goes to the off state. So, the fault current passes through the parallel impedance and is limited by the resonance type FCL, which helps to enhance the FRT capability of the DFIG. Considering the assessment factors, including the deviation of the wind farm terminal voltage, the active power of the wind farm, and the rotor speed of the DFIG, the parallel resonance type FCL has better operation in comparison with the bridge type FCL with parallel resistive-inductive shunt impedance.

\subsection{Superconducting $F C L$}

4.2.1. Inductive Type FCL: Superconducting Fault Current Limiter-Magnetic Energy Storage System (SFCL-MES)

Although, the superconducting FCLs are not of interest for industry from an economical point of view [28], many configurations have been proposed to employ the superconductor for the improvement of the FRT capability of the DFIG. An SFCL-MES has been presented in [33,34]. Its configuration is shown in Figure 9a. In addition to limiting the fault current, the SFCL-MES can smooth the active power fluctuations and stabilize the DC-link voltage. The SFCL has been studied at both the rotor side and the stator side. The SFCL-MES is able to control the superconductor (SC) stored energy and the output power of the DFIG. As previously discussed, placing the inductive FCL either at the stator side or at the rotor side has different impacts. By placing the inductive FCL at the stator side, the stator flux oscillations are limited by decreasing the rotor back-EMF. However, as mentioned before, the rotor transient over-current is not restricted well with the inductive FCL in the stator side, compared to the inductive type FCL placed in the rotor side. In fact, locating the inductive type FCL in the rotor side increases the leakage coefficient more than the inductive type FCL placed in the stator side. However, it may decrease the RSC controllability due to the unchanged rotor back-EMF voltage.

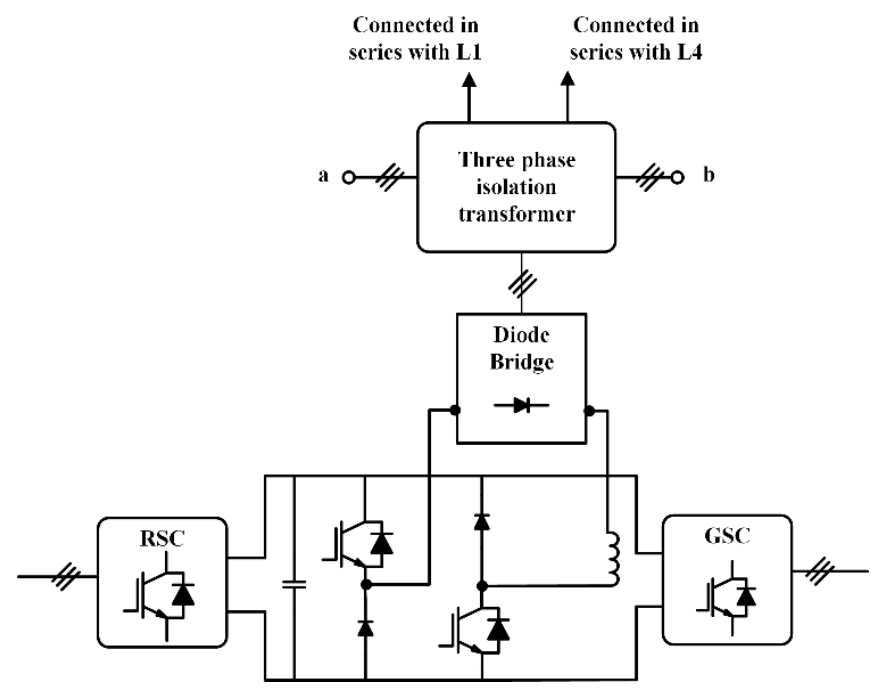

(a)

Figure 9. Cont. 


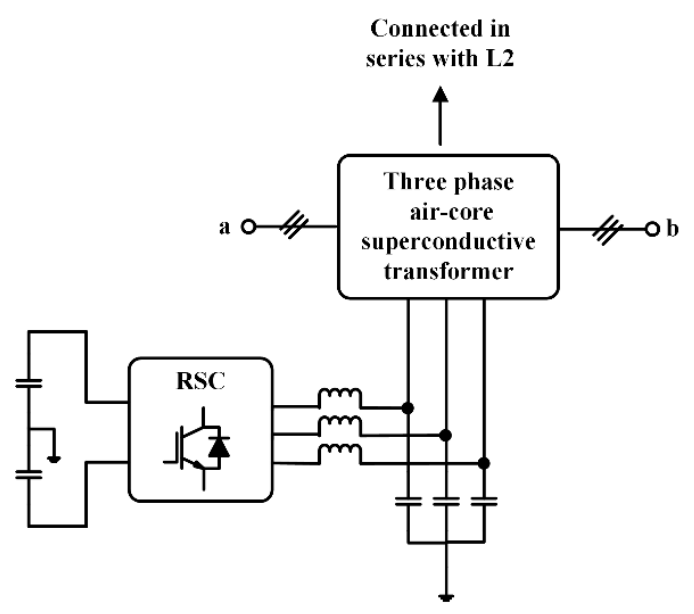

(b)

Figure 9. (a) The superconducting fault current limiter-magnetic energy storage system (SFCL-MES) [33,34]; and (b) the active superconducting fault current limiter [35].

\subsubsection{Inductive Type FCL: Active SFCL with Reactive Power Injection}

An active SFCL, to compensate the voltage sag in the PCC and restrict the fault current level, has been studied in [35], and is shown in Figure 9b. An air-core superconductive transformer is placed in a series connection in the terminal of the DFIG. A three-phase converter with split DC-link capacitors has been connected to the secondary side of the transformer. The converter injects a controlled value of the current to compensate for the voltage drop on the PCC during the fault condition, and to surpass the current level. However, in this configuration, the cost of the superconductor and converter should be taken into account.

\subsubsection{Resistive Type FCL: DC-Resistive SFCL}

In $[36,37]$, a DC-resistive SFCL, shown in Figure 10a, is placed in the PCC to limit the fault current level. There is no novelty, both in the configuration and in the control of the FCL. Furthermore, as mentioned, using the SC increases the installation cost of the structure. In fact, the commercial application of the SFCL might be unavailable due to its high cost.

\subsubsection{Resistive Type FCL: Resistive-Flux-Coupling Type SFCL}

A resistive-flux-coupling type SFCL has been proposed in [38], and is shown in Figure 10b. The SFCL consists of a coupling transformer, an SC, and a semiconductor switch $\left(S_{1}\right)$. Furthermore, an arrestor is employed to overcome the overvoltage in switching instances. In normal operation, $S_{1}$ is closed and if the coupling coefficient is supposed to be one, then the FCL's impedance is almost zero. When a fault happens, $S_{1}$ goes to the off state and the overvoltage is restricted by the arrestor. The SC enters into the fault current pass to limit the current level. It should be noted that placing a resistive impedance in the stator side can be much more effective than in the rotor side, due to the voltage sag compensation and the greater active power absorption. The resistive type FCL in the stator side limits both the stator and rotor currents effectively. 


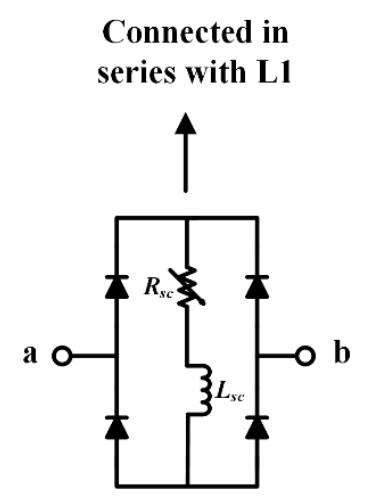

(a)

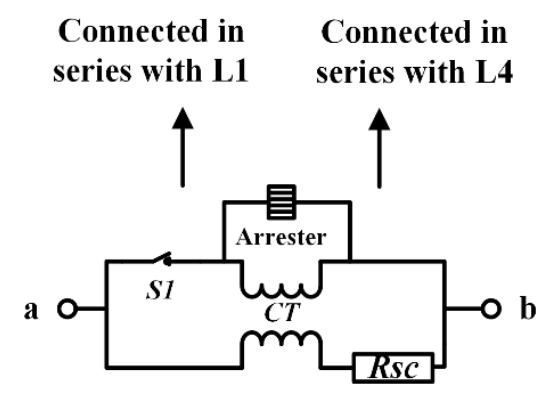

(b)

Figure 10. (a) The DC-resistive superconducting fault current limiter [36]; and (b) the resistive-flux-coupling type superconducting fault current limiter (SFCL) [38].

\subsubsection{Resistive Type FCL: Resistive Type SFCL with Transient Voltage Control (TVC)}

Different configurations of the resistive type SFCL have been placed at the terminal of the DFIG. A resistive type SFCL, cooperated with TVC in the DFIG converters, has been studied in [39]. It has been mentioned that the voltage sag compensation by TVC or the fault current limiting characteristics of the SFCL cannot solely improve the PCC voltage during the fault condition. Post-fault voltage sag compensation in the PCC, by employing the SFCL as a passive voltage compensator, results in a much more reactive power injection by the converters, which act as an active voltage compensator.

\subsubsection{Resistive Type FCL: Superconducting Magnetic Energy Storage (SMES) with the SFCL}

In [40], instead of employing the TVC in the converters, an SMES has been applied together with the SFCL, as shown in Figure 11a. The main application of the SMES is to smooth the active power fluctuation after the fault current limiting by the SFCL. However, in [39], it has been noted that the SFCL is not solely able to effectively improve the PCC voltage.

In [41], the authors modified the configuration of the SFCL-SMES studied in [40]. Instead of utilising two separate SCs (one in the SFCL and another in the SMES), one common SC has been employed in two DC choppers, as shown in Figure 11b. During fault condition, the DC chopper of the FCL enters into the fault current path. After fault removal, the DC chopper of the SMES operates, and the remaining active power fluctuations are restricted as discussed in [40]. 


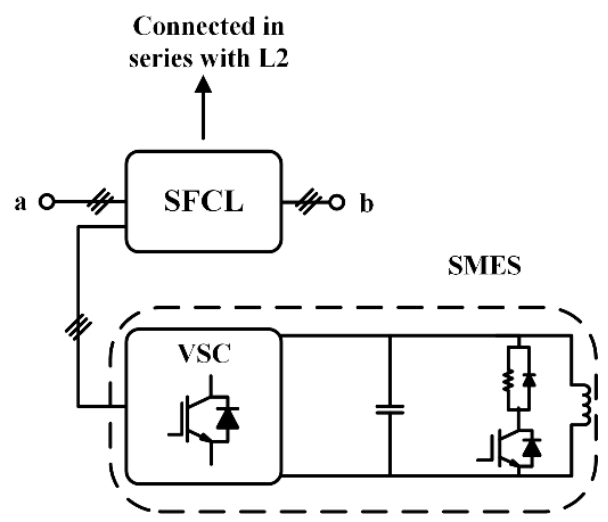

(a)

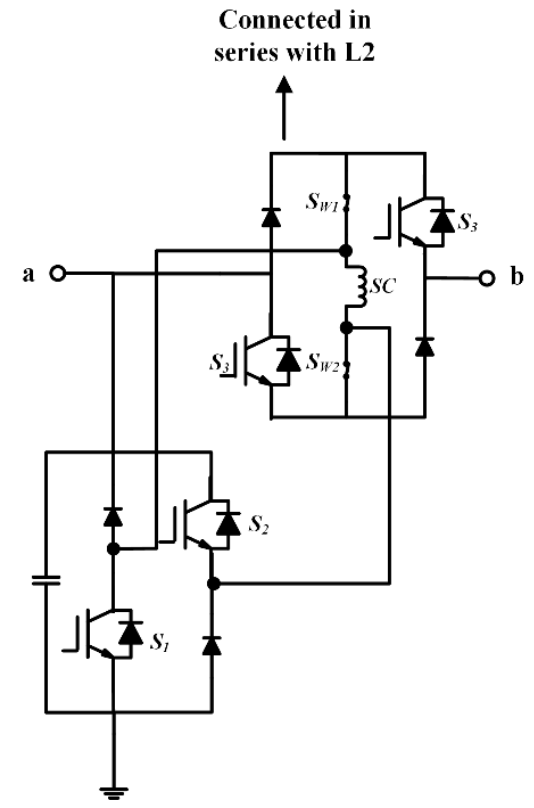

(b)

Figure 11. (a) The superconducting magnetic energy storage (SMES) together the SFCL [40]; and (b) the superconducting fault current limiter with superconducting magnetic energy storage, with common superconductor [41].

\subsubsection{Resistive Type FCL: Resistive Type SFCL in the Rotor Side}

In addition to placing the resistive type SFCL in the terminal of the DFIG, different configurations have been located in the rotor side. In [42,43], the proposed resistive type SFCL in the rotor side operates effectively to limit the rotor transient over-current. Meanwhile, due to active power consumption in the rotor side, the DC-link over-voltage is avoided. However, the RSC controllability gets worse in practice, as mentioned before. Although, the voltage dip in the PCC has been improved by the SFCL in the rotor side, the SFCL in the stator side, either inductive or resistive, has a better performance for voltage sag compensation compared to the rotor side.

In [44], a resistive solid state FCL has been studied in the rotor side. The FCL is composed of antiparallel semiconductor switches, which are employed to bypass or insert the resistance. The FCL operates as a passive compensator to aid the converters to act as an active compensator, as previously discussed in [40]. 


\subsection{Series Dynamic Braking Resistor}

An SDBR can be used to improve the FRT capability of the DFIG. The SDBR is placed in different locations and its impact evaluated. In [45], the SDBR is connected in series with the rotor. The rotor currents have been employed to trigger the SDBR and the active crowbar. The important advantage of the SDBR is to decrease the number of switching operations of the crowbar, which avoids the DFIG operating as a squirrel-cage induction generator during the fault condition. Furthermore, due to limiting the rotor over-current, the frequent performance of the DC braking chopper decreases. This means that the charging current of the DC-link capacitor is reduced by the operation of the SDBR. It should be mentioned that the RSC switching stopped with the SDBR operation. Meanwhile, the SDBR in the rotor side reduces the rotor controllability.

In $[46,47]$, the SDBR is placed at the stator side of the DFIG. Its operation has been compared to the DC braking chopper. As discussed, the current control limiting devices in the stator side are effective for the voltage sag compensation. A summary of advantages and disadvantages of the fault current limiting devices are presented in Table 1. 
Table 1. A summary of characteristics of the fault current limiting devices.

\begin{tabular}{|c|c|c|c|c|c|c|c|c|c|c|c|}
\hline FCL Type & Location & $\begin{array}{l}\text { Impedance } \\
\text { Type }\end{array}$ & $\begin{array}{c}\text { Rotor } \\
\text { Transient } \\
\text { Over-Current } \\
\text { Limitation } \\
\end{array}$ & $\begin{array}{l}\text { Stator Fault } \\
\text { Current } \\
\text { Limitation }\end{array}$ & $\begin{array}{c}\text { Excess Active } \\
\text { Power } \\
\text { Evacuation }\end{array}$ & $\begin{array}{c}\text { Terminal Voltage } \\
\text { Sag } \\
\text { Compensation }\end{array}$ & $\begin{array}{c}\text { Rotor Switching } \\
\text { State during the } \\
\text { Fault }\end{array}$ & $\begin{array}{c}\text { Operation on } \\
\text { Different Types } \\
\text { of Fault }\end{array}$ & Components & SC. & Cost \\
\hline SFCL-MES & L1 and L4 & Inductive & $\begin{array}{l}\text { L1: Yes (G.) } \\
\text { L4: Yes (E.) }\end{array}$ & $\begin{array}{l}\text { L1: Yes (E.) } \\
\text { L4: Yes (G.) }\end{array}$ & No & $\begin{array}{l}\text { L1: Yes (G.) } \\
\text { L4: No }\end{array}$ & $\begin{array}{c}\text { Continuous with } \\
\text { different control, } \\
\text { good } \\
\text { controllability of } \\
\text { the RSC in L1 }\end{array}$ & $\begin{array}{l}\text { Not effective in } \\
\text { asymmetrical } \\
\text { faults }\end{array}$ & $\begin{array}{c}\text { I-T*1 } \\
\text { Diodes }^{*} 6(\mathrm{CSC})^{*} 8(\mathrm{VSC}) \\
\text { Inductor }{ }^{*} 1 \\
\text { S-S }^{*} 0(\mathrm{CSC})^{*}(\mathrm{VSC})\end{array}$ & Yes & High \\
\hline $\begin{array}{l}\text { Switch Type } \\
\text { FCL }\end{array}$ & L1 & Inductive & Yes (G.) & Yes (E.) & No & Yes (G.) & $\begin{array}{l}\text { Continuous with } \\
\text { good RSC } \\
\text { controllability }\end{array}$ & $\begin{array}{l}\text { Not effective in } \\
\text { asymmetrical } \\
\text { faults }\end{array}$ & $\begin{array}{c}\text { I-T*1 } \\
\text { Diode* }^{*} 6 \\
\text { Inductor }{ }^{*} 1 \\
\text { S-S*1 } \\
\text { A snubber circuit }\end{array}$ & No & Low \\
\hline $\begin{array}{c}\text { Active SFCL } \\
\text { with Reactive } \\
\text { Power } \\
\text { Injection }\end{array}$ & L2 & Inductive & Yes (G.) & Yes (E.) & No & Yes (G.) & $\begin{array}{l}\text { Continuous with } \\
\text { good RSC } \\
\text { controllability }\end{array}$ & $\begin{array}{l}\text { Effective for all } \\
\text { fault types }\end{array}$ & $\begin{array}{c}\mathrm{I}^{*} \mathrm{~T}^{*} \text { (superconductive) } \\
\text { A low pass filter } \\
\text { S-S*6 } \\
\text { A split DC-link capacitors }\end{array}$ & Yes & High \\
\hline $\begin{array}{l}\text { DC Resistive } \\
\text { FCL }\end{array}$ & L2 & Resistive & Yes (G.) & Yes (E.) & Yes & Yes (G.) & $\begin{array}{l}\text { Continuous with } \\
\text { good RSC } \\
\text { controllability }\end{array}$ & $\begin{array}{l}\text { Effective for all } \\
\text { fault types }\end{array}$ & $\begin{array}{l}\text { Diodes }{ }^{*} 12 \\
\text { SC }^{* 3}\end{array}$ & Yes & High \\
\hline $\begin{array}{l}\text { Resistive Flux } \\
\text { Coupling Type } \\
\text { SFCL }\end{array}$ & L1 and L4 & Resistive & $\begin{array}{l}\text { L1: Yes (E.) } \\
\text { L4: Yes (G.) }\end{array}$ & $\begin{array}{l}\text { L1: Yes (E.) } \\
\text { L4: Yes (G.) }\end{array}$ & Yes & $\begin{array}{l}\text { L1: Yes (G.) } \\
\text { L4: No }\end{array}$ & $\begin{array}{c}\text { Continuous with } \\
\text { different control, } \\
\text { good } \\
\text { controllability of } \\
\text { the RSC in L1 }\end{array}$ & $\begin{array}{l}\text { Effective for all } \\
\text { fault types }\end{array}$ & $\begin{array}{c}\text { Coupling Transformer*3 } \\
\mathrm{SC}^{* 3} 3 \\
\mathrm{~S}-\mathrm{S}^{* 3} \\
\text { Arrestor*3 }\end{array}$ & Yes & High \\
\hline $\begin{array}{l}\text { Resistive Type } \\
\text { SFCL with } \\
\text { SMES }\end{array}$ & L2 & Resistive & Yes (G.) & Yes (E.) & Yes & Yes (E.) & $\begin{array}{l}\text { Continuous with } \\
\text { good RSC } \\
\text { controllability }\end{array}$ & $\begin{array}{l}\text { Effective for all } \\
\text { fault types }\end{array}$ & $\begin{array}{c}\text { Parallel Transformer*1 } \\
\text { S-S*7 } \\
\text { SC.*4 } \\
\text { Diode }{ }^{* 1} \\
\text { Capacitor }{ }^{* 1}\end{array}$ & Yes & High \\
\hline $\begin{array}{c}\text { Resistive Type } \\
\text { SFCL with } \\
\text { Transient } \\
\text { Voltage } \\
\text { Control }\end{array}$ & L2 & Resistive & Yes (G.) & Yes (E.) & Yes & Yes (E.) & $\begin{array}{c}\text { Continuous with } \\
\text { TVC, good } \\
\text { controllability of } \\
\text { the RSC }\end{array}$ & $\begin{array}{l}\text { Effective for all } \\
\text { fault types }\end{array}$ & SC.*3 & Yes & High \\
\hline
\end{tabular}

I-T: Isolation Transformer; S-S: Semiconductor Switch; Li: Location no.; E.: Excellent; G.: Good; SC.: Superconductor. 
Table 1. Cont.

\begin{tabular}{|c|c|c|c|c|c|c|c|c|c|c|c|}
\hline FCL Type & Location & $\begin{array}{l}\text { Impedance } \\
\text { Type }\end{array}$ & $\begin{array}{c}\text { Rotor } \\
\text { Transient } \\
\text { Over-Current } \\
\text { Limitation }\end{array}$ & $\begin{array}{l}\text { Stator Fault } \\
\text { Current } \\
\text { Limitation }\end{array}$ & $\begin{array}{c}\text { Excess Active } \\
\text { Power } \\
\text { Evacuation }\end{array}$ & $\begin{array}{c}\text { Terminal Voltage } \\
\text { Sag } \\
\text { Compensation }\end{array}$ & $\begin{array}{l}\text { Rotor Switching } \\
\text { State during the } \\
\text { Fault }\end{array}$ & $\begin{array}{c}\text { Operation on } \\
\text { Different Types } \\
\text { of Fault }\end{array}$ & Components & SC. & Cost \\
\hline $\begin{array}{l}\text { Resistive Type } \\
\text { SFCL, SMES } \\
\text { with Common } \\
\text { SC }\end{array}$ & L2 & Resistive & Yes (G.) & Yes (E.) & Yes & Yes (E.) & $\begin{array}{l}\text { Continuous with } \\
\text { good RSC } \\
\text { controllability }\end{array}$ & $\begin{array}{l}\text { Effective for all } \\
\text { fault types }\end{array}$ & $\begin{array}{c}\text { S-S*18 } \\
\text { SC.*3 } \\
\text { Diode } 12 \\
\text { Capacitor*3 }\end{array}$ & Yes & High \\
\hline $\begin{array}{l}\text { Thyristor } \\
\text { Bridge Type } \\
\text { FCL with } \\
\text { Bypass } \\
\text { Resistor }\end{array}$ & L1 & Resistive & Yes (G.) & Yes (E.) & Yes & Yes (E.) & $\begin{array}{l}\text { Continuous with } \\
\text { good RSC } \\
\text { controllability }\end{array}$ & $\begin{array}{l}\text { Not effective in } \\
\text { asymmetrical } \\
\text { faults }\end{array}$ & $\begin{array}{c}\text { I-T*1 } \\
\text { Diode }^{*} 1 \\
\text { Thyristor*6 } \\
\text { Bypass resistor*3 } \\
\text { Inductance*1 }\end{array}$ & No & Low \\
\hline $\begin{array}{c}\text { Variable } \\
\text { Resistive Type } \\
\text { FCL }\end{array}$ & L2 & $\begin{array}{l}\text { Variable } \\
\text { resistance }\end{array}$ & Yes (G.) & Yes (E.) & $\begin{array}{l}\text { Yes, controlled } \\
\text { active power } \\
\text { absorption }\end{array}$ & Yes (E.) & Continuous & $\begin{array}{l}\text { Not effective in } \\
\text { asymmetrical } \\
\text { faults }\end{array}$ & $\begin{array}{c}\text { I-T*1 } \\
\text { Diode*6 }^{*} \\
\text { Inductor*1 } \\
\text { S-S*1 } \\
\text { Resistance*1 }\end{array}$ & No & Low \\
\hline $\begin{array}{l}\text { Optimized } \\
\text { Located FCL }\end{array}$ & L3 & Resistive-ind & ctiveYes (E.) & Yes (G.) & $\begin{array}{l}\text { Yes, the rotor } \\
\text { active power }\end{array}$ & No & Blocked & $\begin{array}{l}\text { Effective for all } \\
\text { fault types }\end{array}$ & $\begin{array}{c}\text { S-S*2 } \\
\text { Resistance } 2 \\
\text { Inductance*2 } \\
\text { Arrestor*2 }\end{array}$ & No & Low \\
\hline $\begin{array}{l}\text { Non-controlled } \\
\text { FCL }\end{array}$ & L1 and L4 & Inductive & $\begin{array}{l}\text { L1: Yes (G.) } \\
\text { L4: Yes (E.) }\end{array}$ & $\begin{array}{l}\text { L1: Yes (E.) } \\
\text { L4: Yes (G.) }\end{array}$ & No & $\begin{array}{l}\text { L1: Yes (G.) } \\
\text { L4: No }\end{array}$ & Continuous & $\begin{array}{l}\text { Effective for all } \\
\text { fault types }\end{array}$ & $\begin{array}{c}\text { I-T*1 } \\
\text { Diode }^{*} 6 \\
\text { Inductor }\end{array}$ & No & Low \\
\hline $\begin{array}{l}\text { Parallel } \\
\text { Resonance } \\
\text { Type FCL }\end{array}$ & L2 & Resonance & Yes (G.) & Yes (E.) & Yes & Yes (E.) & Continuous & $\begin{array}{l}\text { Effective for all } \\
\text { fault types }\end{array}$ & $\begin{array}{c}\text { S-S*3 } \\
\text { Diode }{ }^{*} 15 \\
\text { Inductance } 6 \\
\text { Capacitance*3 } \\
\end{array}$ & No & Low \\
\hline SDBR & L1 and L4 & Resistive & $\begin{array}{l}\text { L1: Yes (G.) } \\
\text { L4: Yes (E.) }\end{array}$ & $\begin{array}{l}\text { L1: Yes (E.) } \\
\text { L4: Yes (G.) }\end{array}$ & Yes & $\begin{array}{l}\text { L1: Yes (G.) } \\
\text { L4: No }\end{array}$ & Blocked & $\begin{array}{l}\text { Effective for all } \\
\text { fault types }\end{array}$ & $\begin{array}{l}\text { Resistance*3 } \\
\text { Thyristor*6 }\end{array}$ & No & Low \\
\hline
\end{tabular}

I-T: Isolation Transformer; S-S: Semiconductor Switch; Li: Location no.; E.: Excellent; G.: Good; SC.: Superconductor. 


\section{Simulation Results}

In this section, the impact of the different locations and the type of impedance for the FCLs are studied. From the FCL's operation point of view, they should have a very low impedance during normal condition, fast response after fault detection, high impedance value during the fault, and also fast recovery time after fault removal. However, various configurations of the FCLs are slightly different in the characteristics mentioned above. For instance, regarding the configuration of the FCLs, some types of FCLs are superconductive, but then have almost zero impedance in normal operation. Whilst for the other types, there is a small impedance. Meanwhile, the FCLs may have different response and recovery times considering their configurations.

However, it should be mentioned that after fault occurrence and during the fault steady state, all FCLs should have a high impedance value and the only difference should be related to the impedance type. Therefore, the type of impedance and its impact on the operation of the DFIG and the FRT enhancement were considered at three different locations, including the stator side, the rotor side, and the terminal side. The DC-link location has the same effect as the rotor side location. So, in order to avoid proliferation, location three was not mentioned. The DFIG was connected to the grid through a three-phase transformer and a transmission line. The parameters of the simulation are presented in Table 2. To have a reasonable comparison, the impedance values for the resistive and inductive type FCLs were the same. Meanwhile, to demonstrate how the FCL's impedance, either as an inductive or a resistive, could affect the RSC controllability, the impedance value was chosen in regards to the FCL impact on the stator side. As discussed, the resistive type FCL in the stator side has a very effective operation because of voltage sag compensation, excess active power consumption, and also increasing the RSC controllability. Therefore, the resistive type FCL in the stator side was selected as a reference to calculate the impedance value.

Table 2. Simulated DFIG Specifications.

\begin{tabular}{|c|c|}
\hline \multicolumn{2}{|c|}{ The DFIG and Transformer } \\
\hline Rated power & $2 \mathrm{MW}$ \\
\hline Three-phase transformer & $0.69 / 34.5 \mathrm{kV}, 60 \mathrm{~Hz}, 5 \mathrm{MVA}$ \\
\hline Rated stator voltage & $690 \mathrm{~V}$ \\
\hline Rated frequency & $60 \mathrm{~Hz}$ \\
\hline Stator leakage inductance & 0.12 p.u. \\
\hline Rotor leakage inductance & 0.12 p.u. \\
\hline Magnetising inductance & 3.45 p.u. \\
\hline Stator to rotor turns ratio & 0.35 \\
\hline Stator resistance & 0.011 p.u. \\
\hline Stator inductance & 0.012 p.u. \\
\hline Nominal wind speed & $13 \mathrm{~m} / \mathrm{s}$ \\
\hline \multicolumn{2}{|c|}{ The DC Chopper } \\
\hline Rated DC-link voltage & $1200 \mathrm{~V}$ \\
\hline DC chopper resistor & $0.5 \Omega$ \\
\hline DC bus capacitor & $50 \mathrm{mF}$ \\
\hline DC-link activation threshold voltage & 1.1 p.u. \\
\hline \multicolumn{2}{|c|}{ Transmission Lines } \\
\hline Length & $30 \mathrm{~km}$ \\
\hline Line impedance & $0.01+\mathrm{j} 0.1 \Omega / \mathrm{km}$ \\
\hline Resistance of grid side filter & 0.3 p.u. \\
\hline Reactance of grid side filter & 0.003 p.u. \\
\hline
\end{tabular}

As mentioned, the different locations have different impacts on the FRT improvement of the DFIG. In this section, the rotor and stator currents are shown in Figure 12. 


\section{Inductive Type Fault Limiter}

Location 1: Stator Side

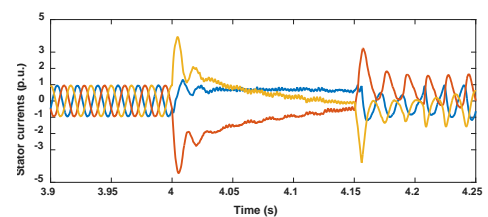

(L1-a)

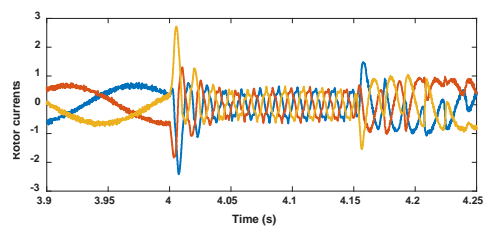

(L1-b)
Location 2: Terminal Side

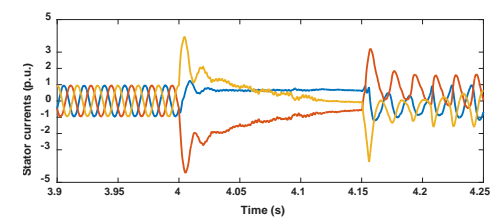

(L2-a)

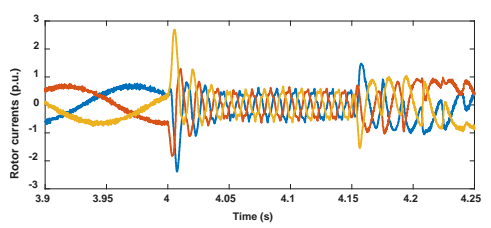

(L2-b)
Location 4: Rotor Side

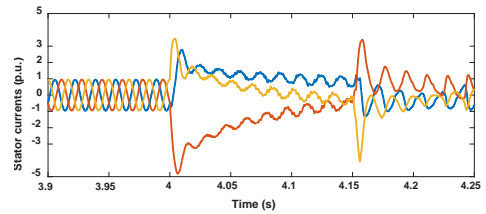

(L4-a)

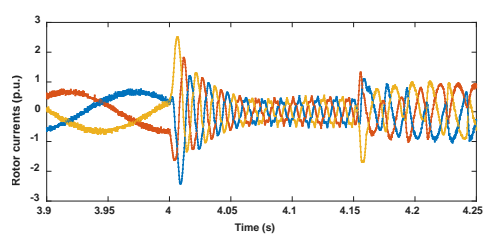

(L4-b)

Figure 12. With the inductive type fault current limiter in the stator side (L1), in the terminal side (L2), and in the rotor side (L4) during a three-phase fault: (a) The stator currents; and (b) the rotor currents.

At first, the inductive type FCL was placed at three locations in the DFIG. The results are presented in Figure 12. The value of the inductance was less than the intersection point inductance value of the leakage coefficient curves presented in Figure $5 b$. Therefore, it can be concluded that the absolute value of the leakage coefficient for the inductive FCL in the rotor side was higher than for the inductive FCL in the stator side. As a result, considering Figure 12 and the discussion in Section 4.1, it is expected that the inductive FCL in the stator side, the rotor side, or the terminal side has almost the same impact on the stator current. Regarding the rotor current shown in Figure 12, for the inductive FCL placed in the rotor side, the rotor fault current level in the steady state of the fault was less than the other FCL locations, due to the high leakage coefficient value shown in Figure $5 \mathrm{~b}$. This point has been discussed in Section 4.1.

The impacts of the resistive type FCL for the three locations are shown in Figure 13. As mentioned, the operation of the FCL with resistive impedance in the stator side was the most effective one in limiting both the stator and rotor currents level. The resistive impedance in the stator side was capable of compensating for the voltage sag in the DFIG terminal, and was also able to absorb excess active power during the fault condition. For the FCL at the terminal side, its impact was almost the same as the FCL placed at the stator side. Regarding Figure 12, due to decreasing the RSC controllability by employing the FCL at the rotor side, there was a high current level in both the stator and rotor sides. However, in order to achieve a good fault current limitation in the rotor side by the FCL, a high impedance value should be employed in the FCL, either in the inductive type FCL or the resistive type FCL.

Considering the results provided for the rotor and the stator currents, the inductive FCL almost had the same impact on the stator current and the rotor current regardless of its location. However, it should be noted that the FCL located in either the stator side or the terminal side had the capability of compensating for the voltage sag in the terminal of the DFIG as well as increasing the RSC controllability. The resistive FCL was most effective in enhancing the FRT capability of the DFIG if it was located in the stator side or the terminal side. Like the inductive FCL, located in the stator or the terminal sides, the resistive FCL could compensate the voltage sag in the terminal and increase the RSC controllability. But, the resistive FCL, located in the stator side or the terminal side, compared to the inductive FCL, located in the stator side or the terminal side, was able to consume excess active power during the fault condition. In fact, from the FRT capability enhancement point of view, the resistive FCL placed in the stator or the terminal sides had the best operation. 


\section{Resistive Type Fault Limiter}

Location 1: Stator Side

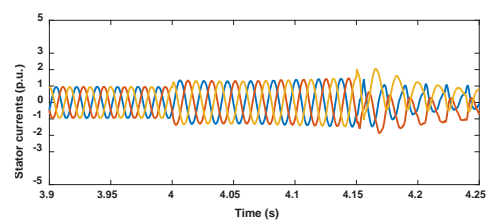

(L1-a)

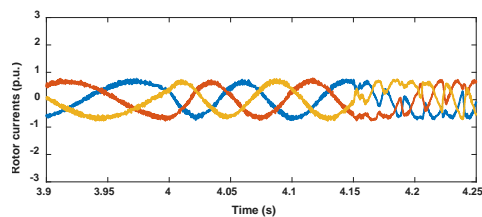

(L1-b)
Location 2: Terminal Side

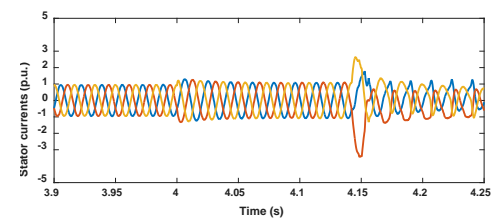

(L2-a)

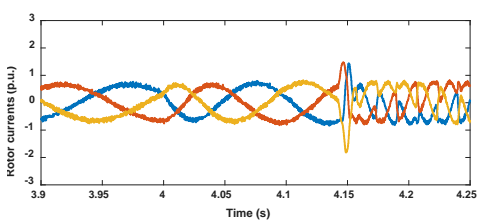

(L2-b)
Location 4: Rotor Side

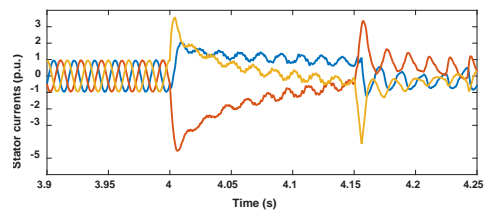

(L4-a)

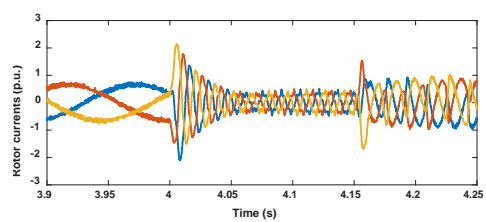

(L4-b)

Figure 13. With the resistive type fault current limiter in the stator side (L1), in the terminal side (L2), and in the rotor side (L4) during a three-phase fault: (a) The stator currents; and (b) the rotor currents.

\section{Conclusions}

In this paper, a review was carried out on the improvement of the fault ride-through capability of the doubly-fed induction generator by use of fault current limiting devices. Almost all of the types of fault current limiters, employed in the fault ride-through of the doubly-fed induction generator, have been discussed. For all prototypes, their cost and the impact of their operation on rotor transient over-current limitation, stator current limitation, excess active power evacuation, and terminal voltage sag compensation have been analysed and provided in Table 1 . With respect to the comparison, the best operation is granted to the resistive type fault current limiter located in the stator side, due to the voltage sag compensation capability in the doubly-fed induction generator terminal, the excess active power consumption, and the increase in controllability of the rotor side converter. As all fault current limiters have the same performance after fault detection, the operation of the fault current limiters was simulated in regards to their location in the doubly-fed induction generator and the impedance types. Three main locations, including the stator side, the rotor side, and the terminal side, were taken into account. Furthermore, for all three locations, the inductive and resistive type fault current limiters were placed, and their impacts on the rotor and stator current limitations were discussed. Regarding the simulation, it was demonstrated that the resistive type fault current limiter placed in the stator side was the most effective fault current limiter in enhancement of the doubly-fed induction generator. For future works, in order to achieve a good fault current limitation with the fault current limiter at the rotor side, the fault current limiter should utilise a high impedance value compared to the fault current limiter located in the stator side. In addition, for fault current limiters in the stator side, a resistive type FCL should be utilised in order to achieve a good fault ride-through capability enhancement in the doubly-fed induction generator.

Author Contributions: All authors equally contributed in conceptualization, methodology, software, formal analysis, investigation, resources, writing-original draft preparation, writing-review \& editing. M.N. and F.B. supervised and administrated the project.

Funding: This research has not received any external funding.

Conflicts of Interest: The authors declare no conflicts of interest.

\section{Abbreviations}

The list of abbreviations used in the paper is provided as follows: 


$\begin{array}{ll}\text { FRT } & \text { Fault Ride-Through } \\ \text { DFIG } & \text { Doubly-Fed Induction Generator } \\ \text { RSC } & \text { Rotor Side Converter } \\ \text { PCC } & \text { Point of the Common Coupling } \\ \text { FCLs } & \text { Fault Current Limiters } \\ \text { SDBRs } & \text { Series Dynamic Braking Resistors } \\ \text { GSC } & \text { Grid Side Converter } \\ \text { EMF } & \text { Electromotive Force } \\ \text { SFCL-MES } & \text { Superconducting Fault Current Limiter-Magnetic Energy Storage System } \\ \text { TVC } & \text { Transient Voltage Control } \\ \text { SMES } & \text { Superconducting Magnetic Energy Storage } \\ \text { STATCOM } & \text { Static Synchronous Compensator } \\ \text { DVR } & \text { Dynamic Voltage Restorers } \\ \text { BTFCL-BR } & \text { Thyristor Bridge Type FCL with Bypass Resistor } \\ \text { NSC } & \text { Non-Superconductor } \\ \text { STFCL } & \text { Switch Type FCL } \\ \text { VR-FCL } & \text { Variable Resistive Type FCL } \\ \text { FLC } & \text { Fuzzy Logic Controller } \\ \text { SNC } & \text { Static Nonlinear Controller } \\ \text { ANFIS } & \text { Adaptive-Network-Based Fuzzy Inference System }\end{array}$

\section{References}

1. Tsili, M.; Papathanassiou, S. A review of grid code technical requirements for wind farms. IET Renew. Power Gener. 2009, 3, 308-332. [CrossRef]

2. Hansen, A.D.; Michalke, G. Fault ride-through capability of DFIG wind turbines. Renew. Energy 2007, 32, 1594-1610. [CrossRef]

3. LÓpez, J.; GubÍa, E.; Sanchis, P.; Roboam, X.; Marroyo, L. Wind turbines based on doubly fed induction generator under asymmetrical voltage dips. IEEE Trans. Energy Convers. 2008, 23, 321-330. [CrossRef]

4. Ma, K. Power Electronics For The Next Generation Wind Turbine System; Springer: Berlin/Heidelberg, Germany, 2015.

5. Netz, E. Grid Code; High and Extra High Voltage; E. ON Netz GmbH: Bayreuth, Germany, 2006; Available online: https: / / www.eon.com/en.html (accessed on 1 August 2018).

6. Justo, J.J.; Mwasilu, F.; Jung, J.-W. Doubly-fed induction generator based wind turbines: A comprehensive review of fault ride-through strategies. Renew. Sustain. Energy Rev. 2015, 24, 447-467. [CrossRef]

7. Duong, M.Q.; Sava, G.N.; Grimaccia, F.; Leva, S.; Mussetta, M.; Costinas, S.; Golovanov, N. Improved LVRT based on coordination control of active crowbar and reactive power for doubly fed induction generators. In Proceedings of the ATEE 2015 9th International Symposium on Advanced Topics in Electrical Engineering, Bucharest, Rome, 7-9 May 2015; pp. 650-655.

8. Huchel, L.; Moursi, M.S.E.; Zeineldin, H.H. A parallel capacitor control strategy for enhanced frt capability of DFIG. IEEE Trans. Sustain. Energy 2015, 6, 303-312. [CrossRef]

9. Pannell, G.; Zahawi, B.; Atkinson, D.J.; Missailidis, P. Evaluation of the performance of a dc-link brake chopper as a dfig low-voltage fault-ride-through device. IEEE Trans. Energy Convers. 2013, 28, 535-542. [CrossRef]

10. Ambati, B.B.; Kanjiya, P.; Khadkikar, V. A low component count series voltage compensation scheme for dfig wts to enhance fault ride-through capability. IEEE Trans. Energy Convers. 2015, 30, 208-217. [CrossRef]

11. Flannery, P.S.; Venkataramanan, G. Unbalanced voltage sag ride-through of a doubly fed induction generator wind turbine with series grid-side converter. IEEE Trans. Ind. Appl. 2009, 45, 1879-1887. [CrossRef]

12. Fathabadi, H. Control of a DFIG-based wind energy conversion system operating under harmonically distorted unbalanced grid voltage along with nonsinusoidal rotor injection conditions. Energy Convers. Manag. 2014, 84, 60-72. [CrossRef]

13. Lopez, J.; Sanchis, P.; Roboam, X.; Marroyo, L. Dynamic behavior of the doubly fed induction generator during three-phase voltage dips. IEEE Trans. Energy Convers. 2007, 22, 709-717. [CrossRef] 
14. Guo, W.Y.; Xiao, L.; Dai, S.T.; Li, Y.H.; Xu, X.; Zhou, W.W.; Li, L. LVRT capability enhancement of DFIG with switch-type fault current limiter. IEEE Trans. Ind. Electron. 2015, 62, 332-342. [CrossRef]

15. Naderi, S.B.; Negnevitsky, M.; Jalilian, A.; Tarafdar Hagh, M.; Muttaqi, K.M. Low voltage ride-through enhancement of DFIG-based wind turbine using DC link switchable resistive type fault current limiter. Int. J. Electr. Power Energy Syst. 2017, 86, 104-119. [CrossRef]

16. Xie, D.L.; Xu, Z.; Yang, L.H.; Østergaard, J.; Xue, Y.H.; Wong, K.P. A comprehensive LVRT control strategy for DFIG wind turbines with enhanced reactive power support. IEEE Trans. Power Syst. 2013, 28, 3302-3310. [CrossRef]

17. Rahimi, M.; Parniani, M. Efficient control scheme of wind turbines with doubly fed induction generators for low-voltage ride-through capability enhancement. IET Renew. Power Gener. 2010, 4, 242-252. [CrossRef]

18. Kanjiya, P.; Ambati, B.B.; Khadkikar, V. A novel fault-tolerant DFIG-based wind energy conversion system for seamless operation during grid faults. IEEE Trans. Power Syst. 2014, 29, 1296-1305. [CrossRef]

19. Flannery, P.S.; Venkataramanan, G. A fault tolerant doubly fed induction generator wind turbine using a parallel grid side rectifier and series grid side converter. IEEE Trans. Power Electron. 2008, 23, 1126-1135. [CrossRef]

20. Qiao, W.; Harley, R.G.; Venayagamoorthy, G.K. Coordinated reactive power control of a large wind farm and a STATCOM using heuristic dynamic programming. IEEE Trans. Energy Convers. 2009, 24, 493-503. [CrossRef]

21. Qiao, W.; Harley, R.G.; Venayagamoorthy, G.K. Effects of FACTS devices on a power system which includes a large wind farm. In Proceedings of the 2006 IEEE PES Power Systems Conference and Exposition, Atlanta, GA, USA, 29 October-1 Novermber 2006; pp. 2070-2076.

22. Ibrahim, A.O.; Nguyen, T.H.; Lee, D.C.; Kim, S.C. A fault ride-through technique of DFIG wind turbine systems using dynamic voltage restorers. IEEE Trans. Energy Convers. 2011, 26, 871-882. [CrossRef]

23. Hagh, M.T.; Naderi, S.B.; Jafari, M. Application of non-superconducting fault current limiter to improve transient stability. In Proceedings of the 2010 IEEE International Conference on Power and Energy, Kuala Lumpur, Malaysia, 29 Novermber-1 December 2010; pp. 646-650.

24. Naderi, S.B.; Negnevitsky, M.; Jalilian, A.; Hagh, M.T.; Muttaqi, K.M. Optimum resistive type fault current limiter: An efficient solution to achieve maximum fault ride-through capability of fixed-speed wind turbines during symmetrical and asymmetrical grid faults. IEEE Trans. Ind. Appl. 2017, 53, 538-548. [CrossRef]

25. Jafari, M.; Naderi, S.B.; Hagh, M.T.; Abapour, M.; Hosseini, S.H. Voltage sag compensation of point of common coupling (PCC) using fault current limiter. IEEE Trans. Power Deliv. 2011, 26, 2638-2646. [CrossRef]

26. Naderi, S.B.; Negnevistky, M.; Jalilian, A.; Hagh, M.T. Non-controlled fault current limiter to improve fault ride through capability of DFIG-based wind turbine. In Proceedings of the 2016 IEEE Power and Energy Society General Meeting (PESGM), Boston, MA, USA, 17-21 July 2016; pp. 1-5.

27. Mardani, M.; Fathi, S.H. Fault current limiting in a wind power plant equipped with a DFIG using the interface converter and an optimized located FCL. In Proceedings of the 6th Power Electronics, Drive Systems \& Technologies Conference (PEDSTC2015), Tehran, Iran, 3-4 February 2015; pp. 328-333.

28. Guo, W.; Xiao, L.; Dai, S.; Xu, X.; Li, Y.; Wang, Y. Evaluation of the performance of BTFCLS for enhancing lvrt capability of DFIG. IEEE Trans. Power Electron. 2015, 30, 3623-3637. [CrossRef]

29. Hossain, M.K.; Ali, M.H. Transient stability augmentation of PV/DFIG/SG-based hybrid power system by nonlinear control-based variable resistive FCL. IEEE Trans. Sustain. Energy 2015, 6, 1638-1649. [CrossRef]

30. Naderi, S.B.; Jafari, M.; Tarafdar Hagh, M. Controllable resistive type fault current limiter (CR-FCL) with frequency and pulse duty-cycle. Int. J. Electr. Power Energy Syst. 2014, 61, 11-19. [CrossRef]

31. Rashid, G.; Ali, M.H. Application of parallel resonance fault current limiter for fault ride through capability augmentation of DFIG based wind farm. In Proceedings of the 2016 IEEE/PES Transmission and Distribution Conference and Exposition (T \& D), Dallas, TX, USA, 2-5 May 2016; pp. 1-5.

32. Naderi, S.B.; Jafari, M.; Hagh, M.T. Parallel-resonance-type fault current limiter. IEEE Trans. Ind. Electron. 2013, 60, 2538-2546. [CrossRef]

33. Guo, W.; Xiao, L.; Dai, S. Enhancing low-voltage ride-through capability and smoothing output power of DFIG with a superconducting fault-current limiter magnetic energy storage system. IEEE Trans. Energy Convers. 2012, 27, 277-295. [CrossRef]

34. Guo, W.; Xiao, L.; Dai, S. Fault current limiter-battery energy storage system for the doubly-fed induction generator: Analysis and experimental verification. IET Gener. Trans. Distrib. 2016, 10, 653-660. [CrossRef] 
35. Chen, L.; Zheng, F.; Deng, C.; Li, Z.; Guo, F. Fault ride-through capability improvement of DFIG-based wind turbine by employing a voltage-compensation-type active SFCL. Can. J. Elect. Comput. Eng. 2015, 38, $132-142$. [CrossRef]

36. Hossain, M.M.; Ali, M.H. Transient stability improvement of doubly fed induction generator based variable speed wind generator using DC resistive fault current limiter. IET Renew. Power Gener. 2016, 10, 150-157. [CrossRef]

37. Hossain, M.; Ali, H. Asymmetric fault ride through capability enhancement of DFIG based variable speed wind generator by DC resistive fault current limiter. In Proceedings of the 2016 IEEE/PES Transmission and Distribution Conference and Exposition (T \& D), Dallas, TX, USA, 2-5 May 2016.

38. Chen, L.; Deng, C.; Zheng, F.; Li, S.; Liu, Y.; Liao, Y. Fault ride-through capability enhancement of DFIG-based wind turbine with a flux-coupling-type SFCL employed at different locations. IEEE Trans. Appl. Supercond. 2015, 25, 15. [CrossRef]

39. Ou, R.; Xiao, X.Y.; Zou, Z.C.; Zhang, Y.; Wang, Y.H. Cooperative control of SFCL and reactive power for improving the transient voltage stability of grid-connected wind farm with DFIGs. IEEE Trans. Appl. Supercond. 2016, 26, 1-6. [CrossRef]

40. Ngamroo, I.; Karaipoom, T. Cooperative control of SFCL and SMES for enhancing fault ride through capability and smoothing power fluctuation of dfig wind farm. IEEE Trans. Appl. Supercond. 2014, 24, 1-4. [CrossRef]

41. Ngamroo, I.; Karaipoom, T. Improving low-voltage ride-through performance and alleviating power fluctuation of DFIG wind turbine in dc microgrid by optimal smes with fault current limiting function. IEEE Trans. Appl. Supercond. 2014, 24, 1-5. [CrossRef]

42. Zou, Z.C.; Chen, X.Y.; Li, C.S.; Xiao, X.Y.; Zhang, Y. Conceptual design and evaluation of a resistive-type SFCL for efficient fault ride through in a DFIG. IEEE Trans. Appl. Supercond. 2016, 26, 1-9. [CrossRef]

43. Zou, Z.C.; Xiao, X.Y.; Liu, Y.F.; Zhang, Y.; Wang, Y.H. Integrated protection of DFIG-based wind turbine with a resistive-type SFCL under symmetrical and asymmetrical faults. IEEE Trans. Appl. Supercond. 2016, 26, 1-5. [CrossRef]

44. Mohammadi, J.; Afsharnia, S.; Vaez-Zadeh, S.; Farhangi, S. Improved fault ride through strategy for doubly fed induction generator based wind turbines under both symmetrical and asymmetrical grid faults. IET Renew. Power Gener. 2016, 10, 1114-1122. [CrossRef]

45. Yang, J.; Fletcher, J.E.; O'Reilly, J. A series-dynamic-resistor-based converter protection scheme for doubly-fed induction generator during various fault conditions. IEEE Trans. Energy Conver. 2010, 25, 422-432. [CrossRef]

46. Okedu, K.E. Enhancing DFIG wind turbine during three-phase fault using parallel interleaved converters and dynamic resistor. IEEE Trans. Energy Conver. 2016, 10, 1211-1219. [CrossRef]

47. Okedu, K.E.; Muyeen, S.M.; Takahashi, R.; Tamura, J. Wind farms fault ride through using DFIG with new protection scheme. IEEE Trans. Sustain. Energy 2012, 3, 242-254. [CrossRef] 